\title{
Development of a polymerase chain reaction for the detection of abalone herpesvirus infection based on the DNA polymerase gene
}

\author{
M.H. Chen ${ }^{\mathrm{a}, \mathrm{c}}$, S.T. Kuo ${ }^{\mathrm{b}}$, T. Renault ${ }^{\mathrm{d}}$, C.S. Friedman ${ }^{\mathrm{e}}$, P.H. Chang ${ }^{\mathrm{a}, *}$
}

\footnotetext{
${ }^{a}$ Institute of Veterinary Medicine, School of Veterinary Medicine, National Taiwan University, Taipei, Taiwan

${ }^{\mathrm{b}}$ National Institute for Animal Health, Tansui, Taiwan

${ }^{c}$ Tzu Chi College of Technology, Hualien, Taiwan

d Ifremer, Laboratoire de Génétique et Pathologie, 17390 La Tremblade, France

e School of Aquatic and Fishery Sciences, University of Washington, Seattle, WA, USA
}

*: Corresponding author : P. H. Chang, Tel.: +8862 33661296 ; fax: +886 223661475 ;

email address : penheng@ntu.edu.tw

\begin{abstract}
:
A 5781-base pair (bp) fragment of genomic DNA from the Taiwanese abalone herpesvirus was obtained and showed 99\% (5767/5779) homology in the nucleotide sequence and 99\% (1923/1926) in the amino acid sequence with the DNA polymerase gene of the abalone herpesvirus strain Victoria/AUS/2007. Homology of the amino acid sequence with the DNA polymerase of ostreid herpesvirus 1 was $30 \%(563 / 1856)$. In this study, a PCR-based procedure for detecting herpesvirus infection of abalone, Haliotis diversicolor supertexta, in Taiwan was developed. The method employed primer sets targeting the viral DNA polymerase gene, and was able to amplify DNA fragments of the expected size from infected samples. Primer sets of $40 \mathrm{f}$ and $146 \mathrm{r}$ were designed for amplification of an expected PCR product of $606 \mathrm{bp}$. Combining the new PCR protocol with histopathology, this assay can serve as a reliable diagnostic for herpesvirus infections in abalone.
\end{abstract}

\section{Highlights}

Sequencing of the abalone herpesvirus from field cases was carried out. A PCR was developed from the DNA polymerase of herpesvirus for detecting herpesvirus infections in abalone. $D$ This test is a useful method for epidemiological studies of abalone herpesvirus in the field.

Keywords: Herpes virus ; Abalone ; Haliotis diversicolor supertexta ; DNA polymerase ; Polymerase chain reaction 


\section{Introduction}

Herpesvirus infections have been reported in various marine bivalve

41 molluscs worldwide since the early 1990s. The first description of a virus

42 morphologically similar to members of the Herpesvirales (Davison et al., 2009)

43 in a bivalve mollusk was in the eastern oyster, Crassostrea virginica in 1972

44 (Farley et al., 1972). A wide host range was then reported for herpesvirus

45 infections in bivalves including various species of oysters, clams, and scallops

46 (Renault and Novoa, 2004 ; Renault, 2008 ; Burge et al., 2011). Mortality of

47 abalone (molluscan genus Haliotis) associated with herpes-like viral

48 pathogens has been reported in several species and subspecies including $H$.

49 discus discus (Otsu and Sasaki, 1997; Nakatsugawa et al., 1999), H. discus

50 hannai (Wang and Li, 1997), H. diversicolor Reeve (Wang et al., 2000), $H$.

51 diversicolor aquatilis (Song et al., 2000), and H. diversicolor supertexta (Zhang

52 et al., 2001). Recent outbreaks of infection with a herpesvirus, Haliotis

53 herpesvirus (AbHV) that induced acute and high mortality were described in

54 cultured abalone, H. diversicolor supertexta, in Taiwan (Chang et al., 2005). A

55 herpesvirus identified as Haliotis herpesvirus $1(\mathrm{AbHV}-1)$ also induced

56 mortality in abalone including blacklip abalone $H$. rubra, greenlip abalone $H$.

57 laeviga, and their hybrids in Australia. However, clinical signs of Australian 
58 AbHV infection differed from those of the Taiwanese abalone in that moribund

59 Australian abalone had a swollen mouth and prolapsed odontophore (Hooper

60 et al., 2007), while those in Taiwan diseased abalone exhibited mantle

61 recession and muscle atrophy (Chang et al., 2005), but lacked the oral lesions

62 observed in Australia.

$63 \mathrm{AbHV}$ is a neurotropic virus causing ganglioneuritis; abalone 1 year or

64 older are typically affected (Huang et al., 1999; Chang et al., 2005). Lesions

65 include necrosis of the cerebral ganglia and nerve bundles in the muscle of the

66 foot as well as in the muscular layers beneath the visceral organs (Chang et al.,

67 2005). Similar neurological involvement, also noted as ganglioneuritis was

68 reported in the blacklip abalone and greenlip abalone by Hooper et al., (2007).

69 A herpes-like virus was also reported from abalone causing amyotrophia

70 characterized by the development of tumour-like lesions in the nerve trunk of

71 Japanese black abalone, H. (=Nordotis) discus discus (Nakatsugawa et al., 72 1999).

73 Light microscopy has been used to diagnose both AbHV and AbHV-1

74 infections due to the prominent neurological lesions induced by these viruses

75 in Taiwan and Australia, respectively (Chang et al., 2005; Hooper et al., 2007).

76 Additional techniques, such as transmission electron microscopy, can be used 
77 to confirm the diagnosis. Both microscopic techniques are time consuming and

78 inadequate for epidemiological studies because herpesviruses may persist in

79 clinically healthy hosts (carrier or latent-state infection) and recur under

80 stressful conditions (Whitley, 1996). Thus rapid, high-throughput molecular

81 diagnostic methods are needed to aid in diagnosing AbHV.

82 The genome sequencing of one bivalve herpesvirus, ostreid herpesvirus

83 (OsHV)-1, allowed the development of DNA-based diagnostic techniques.

84 Polymerase chain reaction (PCR)-based methods for detecting OsHV-1 DNA

85 isolated from fresh, frozen and paraffin-embedded samples were previously

86 published (Renault et al., 2000 ; Barbosa-Solomieu et al., 2004 ; Batista et al.,

872007 ; Martenot et al., 2010 ; Segarra et al., 2010). Different OsHV-1-specific

88 primer sets $(n=20)$ were used on abalone samples from Taiwan, but failed to

89 amplify DNA from AbHV-infected abalone (Chang and Renault, unpubl. data).

90 A TaqMan® PCR-based technique specific for gene containing motifs $\mathrm{V}$ and $\mathrm{VI}$,

91 characteristic of SF2 helicase was available for detection of herpesvirus

92 infections in abalone (OIE 2009; Corbeil et al., 2010).

93 Although the DNA polymerase gene seems to be highly conserved, some

94 differences did exist between virus isolates from Taiwan and Australia. Thus,

95 this virus gene appears of interest for generic diagnosis purpose to detect most 
of virus isolates in the field. In the present study a conventional PCR technique

97 targeting the AbHV DNA polymerase gene was developed and tested on

98 abalone samples from field locations (farms).

99

100

\section{Materials and methods}

101

\subsection{Biological materials}

102

AbHV-infected abalone, H. diversicolor supertexta, collected from a

103 grow-out farm that suffered high mortalities in 2004 in northern Taiwan were

104 used as the material source. Abalone collected from farms in southern Taiwan

105 with no history of AbHV infection were used as negative controls. Nerve

106 tissues of 300 moribund abalones collected from one batch from a

107 AbHV-affected farm were excised and held at $-80^{\circ} \mathrm{C}$ until DNA extraction.

108 Nerve tissues of 300 control abalones were also excised and similarly stored.

109 2.2. Viral purification, negative staining and DNA Extraction

110 AbHV was purified using methods modified from Le Deuff and Renault (1999)

111 and Tan et al., (2008). Briefly, $2 \mathrm{~g}$ of pleuropedal ganglia, pedal nerve cords,

112 head and epipodial tissue from AbHV-infected abalone was used to purify virus

113 particles. Cells were lysed using a combination of homogenization and

114 sonication. Viral particles were separated from abalone nervous tissues by a 
115 discontinuous sucrose gradient composed of five fractions, of $60 \%, 50 \%, 40 \%$,

$11630 \%$, and $10 \%$ sucrose $(\mathrm{w} / \mathrm{v})$, prepared in seawater followed by

117 ultracentrifugation at $112,398 \times g(25,000 \mathrm{rpm}$ using an SW28 rotor, Beckman,

118 Brea, California, USA) for $1 \mathrm{~h}$ at $4{ }^{\circ} \mathrm{C}$. Fractions (1 2 ml) were collected at

119 each interface, and each corresponding fractions were pooled from different

120 gradient tubes. Fractions were diluted four times by adding seawater in a

121 drop-wise manner, and the virus was pelleted at $300,000 \mathrm{xg}$ for $90 \mathrm{~min}$ (Le

122 Deuff and Renault, 1999). DNA from the virus pellets was extracted using a

123 QIAamp Stool Mini Kit (QIAgen, Hilden, Germany) following the manufacturer's

124 instructions. A portion of the purified virus pellets $(100 \mu \mathrm{L})$ was centrifuged at

$125100,000 \times g$ for 10 min, negatively stained with $2 \%$ phosphotungstic acid and

126 examined with electron microscopy (Hitachi, HF-3300, Tokyo, Japan) (Bozzola

127 and Russell, 1992).

128 2.3. DNA Sequencing

129 Approximately $5 \mu \mathrm{g}$ of genomic DNA from ganglia and nerve cords was

130 sheared by nebulization, and DNA sequencing was performed following

131 protocols for the Genome Sequencer GS FLX Titanium System (Roche,

132 Branford, Connecticut, USA). Reads generated by the GS FLX sequencer

133 were trimmed of low-quality sequences and were assembled by a GS de novo 
134 Assembler. These sequences were compared using the NCBI blastx program

135 (http://blast.ncbi.nlm.nih.gov). A gene homologous to the DNA polymerase of a

136 herpesvirus was chosen in this study. Analyses were performed and

137 sequences aligned using Phylogenetic Inference with the Automatic Likelihood

138 Model (PALM) (Braithwaite and Ito, 1993; Chen et al., 2009).

139 2.4. PCR for the detection of Haliotis herpesvirus

140 PCR primers were designed from the above sequences using the program

141 Primer3. Primers of 40f (5'-TCCATCGAGATTCCCAGTTC-3') and 146r

142 (5'-ACGCCACCCTGTATAACGAG-3') were expected to yield a 606 bp PCR

143 product. PCR amplification was performed as described by Renault et al.,

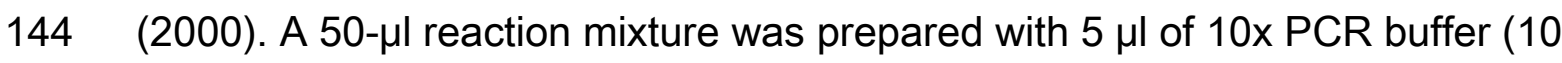

$145 \mathrm{mM}$ Tris- $\mathrm{HCl}, 50 \mathrm{mM} \mathrm{KCl}, 1.5 \mathrm{mM} \mathrm{MgCl}$, and $0.001 \% \mathrm{w} / \mathrm{v}$ gelatin), $400 \mu \mathrm{M}$

$146 \mathrm{dNTPs}, 5 \mu \mathrm{M}$ tetramethylammonium chloride, 40 pmoles of each primer, $2 \mu \mathrm{l}$

147 purified DNA, and $2 \mathrm{U}$ of Taq polymerase, and was brought up to volume with

148 sterile distilled water. PCR amplification was performed in a thermocycler

149 (PTC-100, MJ Research, Alameda, CA , USA) with an initial denaturation step

150 of $94{ }^{\circ} \mathrm{C}$ for $2 \mathrm{~min}$, followed by 35 cycles of $1 \mathrm{~min}$ of denaturation at $94^{\circ} \mathrm{C}, 1$

151 min of annealing at $52{ }^{\circ} \mathrm{C}$, and a 1 -min extension at $72{ }^{\circ} \mathrm{C}$, followed by

152 incubation for $5 \mathrm{~min}$ at $72{ }^{\circ} \mathrm{C}$. Control PCRs without a template were used to 
153 test for cross-contamination. All reactions were tested in triplicate. Amplified

154 fragments were separated using a $1 \%$ agarose gel and visualized with UV

155 illumination after staining with ethidium bromide. The presence of amplifiable

156 DNA was confirmed in all negative samples using 18 S ribosomal RNA gene

157 primers kindly supplied by Dr. Mark Crane (CSIRO Livestock Industries,

158 Victoria, Australia). Primer sets of $18 \mathrm{~S}$ forward

159 (5'-GGCTACCACATCCAAGGAA-3') and 18S reverse

160 (5'-GCTGGAATTACCGCGGCT-3') were used in this study, and the procedure

161 was carried out as described previously (Corbeil et al., 2010).

162

\subsection{Histolopathology and PCR concordance analysis} Batches were selected for the analysis based on mortality and low harvest

164 rates of grow-out farms in an epizootic area. Archived samples collected

165 between 2003 and 2009 from farms that showed persistent low rate mortality

166 and high cumulative mortality associated with undertermined etiologies were

167 inlcuded in this analysis. Samples of visceral organs were fixed in $10 \%$

168 seawater formalin, embedded in paraffin, sectioned at $5 \mu \mathrm{m}$, and stained with

169 Mayer's haematoxylin and eosin (H\&E) and examined by light microscopy.

170 Results of histolpathology and PCR were recorded. 


\section{Results}

\subsection{Nucleotide sequencing and sequence alignment}

A 5781-bp fragment of AbHV showed 99\% (5767/5779) homology with the

(AbHV-1). When translated to its predicted amino acid sequence, the selected AbHV fragment also showed high sequence identity (99\%; 1923/1926) with that of AbHV-1. AbHV showed moderate amino acid sequence identity (30\%; $562 / 1856)$ with that of OsHV-1. This fragment of AbHV also showed moderate to low amino acid sequence identities (23\% 46\%) with the DNA polymerase of

181 other herpesviruses (Table 1). The nucleotide sequence of the AbHV DNA 182 polymerase gene of the virus isolate from Taiwan has been deposited in 183 GenBank under accession number HQ317456. Herpesvirales order illustrated that the abalone herpesvirus forms a

187 abalone herpesvirus from Taiwan, and OsHV-1 clustered in the same

188 subgroup based on the DNA polymerase sequence data. 
The 40 and 146r AbHV primers amplified the expected PCR product of

191606 bp from DNA of moribund abalone. No amplification was observed when

192 eel herpesvirus DNA, koi herpesvirus DNA, chicken infectious laryngotracheitis

193 virus DNA, or OsHV-1 DNA served as irrelevant controls (Fig. 2).

194 3.3. Histopathology

195 Ganglioneuritis lesions were present in ganglia and nerve tracts of various

196 tissues in PCR-positive samples. These lesions were characterized by tissue

197 necrosis accompanied by infiltration of haemocytes; inclusion bodies were rare.

198 Haemocytes were also observed surrounding the neurilemma (Fig. 3a, b).

199 3.4. Electron microscopy

200 A negative-contrast electron microscopy demonstrated viral particles at

201 the interface of the $40 \% \sim 50 \%$ layers of the sucrose gradients. Viral particles

202 were hexagonal, 90 100 nm in diameter, and had a single coat (Fig. 4).

203 3.5. Histolopathology and PCR concordance analysis

204 Histopathology and PCR data showed 100\% concordance. Samples from

2056 out of 19 batches examined showed both histological evidence of

206 ganglioneuritis and PCR evidence of AbHV DNA presence. All of the

207 remaining 13 batches of samples from which no AbHV DNA was amplified also

208 lacked histopathological evidence of ganglioneuritis (Table 2). No virions were 
209 observed via electron microscopy using direct negative staining of pooled

210 organs including nerve tissues, the hepatopancreas, gonads, gills, and

211 intestines in any animlas from PCR and histology-negative batches. However,

212 these samples have experienced elevated mortality of unknown etiology in the

213 field.

215 4. Discussion

216 For the first time, this study provides information on the phylogeny of the

217 Taiwanese herpesvirus infecting the abalone, H. diversicolor supertexta. In this

218 study, partial genome sequences of a 5781-bp fragment from the Taiwanese

219 AbHV DNA polymerase gene showed nearly identical DNA and deduced

220 amino acid sequence (99\%) homologies with those of the abalone

221 Victoria/AUS/2007 (AbHV-1). In contrast, AbHV showed moderate amino acid

222 sequence identity (30\%) with that of OsHV-1, which infects bivalves, and

$22323 \% \sim 46 \%$ identity with some vertebrate herpesviruses. The phylogenic

224 analysis showed that the AbHV isolate from Taiwan is a member of the

225 Herpesvirales. In this study, AbHV isolate from Taiwan, AbHV-1 and OsHV-1

226 were clustered in the same subgroup based on DNA polymerase sequence

227 data (Fig. 1). However, analysis of large genome fragments of the AbHV virus 
228 isolate from Taiwan using the supermatcher program revealed that the TC04

229 fragment of the Taiwanese isolate (NCBI accession no. JN083851) had 85.7\%

230 (10481/12224) identity to the Victoria/AUS/2007 AbHVscaffold_3172-3200

231 fragment. The TC02 (NCBI accession no. JF967012) and TC08 fragments

232 (NCBI accession no. HQ890941) of the Taiwanese isolate corresponded to the

233 Victoria/AUS/2007 AbHVscaffold_3197-3033 isolate, and had 66.7\%

$234(26,884 / 40,281)$ and $61.2 \%(14,529 / 23,756)$ identities, respectively. These

235 results suggested that the Taiwan virus isolate, Taiwan/2004, is

236 distinguishable from AbHV-1 (Australia isolate, Victoria/AUS/2007).

237 No OsHV-1 and AbHV belong both to Malacoherpesviridae family. A

238 phylogenic analysis of deducted protein sequences from DNA polymerase and

239 terminase genes showed that although OsHV-1 and AbHV appear to belong to

240 the family Malacoherpesviridae, they are in fact distantly related, and the

241 putative amphioxus herpesvirus shares more sequence similarity to mollusk

242 herpesviruses than to sequences from any of the vertebrate herpesviruses

243 analyzed (Savin et al., 2010). To accommodate this abalone virus, Savin et al.,

244 (2010) suggested creating a new genus called Haliotivirus within the

245 Malacoherpesviridae family and assigning the virus infecting abalone in

246 Australia as a species under Haliotivirus (as Haliotid herpesvirus 1). Although 
247 AbHV isolate from Taiwan showed some sequence homology with OsHV-1,

248 neither virus is similar enough to be detected using existing primers targeting

249 OsHV-1. Indeed, the primer pairs (C1/C6, C1/C4, C2/C4, C2/C6, C5/C13,

$250 \mathrm{C} / \mathrm{C} 10, \mathrm{~A} 3 / \mathrm{A} 4, \mathrm{~A} 5 / \mathrm{A} 6, \mathrm{~B} 1 / \mathrm{B} 2, \mathrm{~B} 3 / \mathrm{B} 2, \mathrm{~B} 3 / \mathrm{B} 4, \mathrm{Gp} 1 / \mathrm{Gp} 2, \mathrm{Gp} 1 / \mathrm{Gp} 4, \mathrm{Gp} 1 / \mathrm{Gp} 10$,

251 Gp3/Gp4, Gp7/ Gp8, Gp9/Gp10, Gp10/Gp15, IA1/1A2, IA3/IA6) (Arzul et al.,

252 2001a, b, 2002; Renault and Arzul, 2001; Renault, pers. comm.) failed to

253 amplify DNA from AbHV-infected samples from Taiwan (Chang and Renault,

254 pers comm). Thus, AbHV and OsHV-1 may represent two viral species, the

255 former infecting gastropods and the latter infecting bivalves.

256 A conventional PCR for detecting AbHV was developed in the present

257 study targeting the DNA polymerase gene. Indeed, some differences were

258 reported between virus isolates from Taiwan and Australia. The DNA

259 polymerase gene appears of interest for detecting most of virus isolates in the

260 field. A clear advantage of the designed primer set is its application on abalone

261 samples from field locations. Application of the primer set (40f/146r) yielded

262 amplicons of the expected size when DNA samples extracted from infected

263 abalone were used as templates. This amplification was specific, since no

264 fragment was amplified from irrelevant control abalone DNA, or DNA from 
265 different herpesviruses, including a OsHV-1, a koi herpesvirus (KHV), an eel

266 herpesvirus, OsHV-1, and an avian herpesvirus.

267 Although major neural tissues appeared to be prominently involved in the

268 disease process, viral DNA was also amplified from the intestines, gills,

269 hepatopancreas, gonads, muscles, and mantle (data not shown). In the field,

270 recurrence of $\mathrm{AbHV}$ in abalones on farms following strict disinfection has been

271 noticed in successive years. Severe mortality occurred following low water

272 temperatures suggesting the possible persistence of AbHV on farms and

273 reactivation of the the virus infection by stress (Van Nieuwstadt et al., 2001).

274 However, more studies are needed to verify the relationship between stress

275 and AbHV infection of abalone. Development of diagnostic procedures for

276 detecting early infections of AbHV in abalones would be useful. Results of this

277 study will facilitate epidemiological investigations to ascertain whether other

278 mollusks in this area may be infected. Histopathology or electron microscopy

279 would also be required to confirm AbHV infection (OIE 2009). A retrospective

280 study using this primer set to analyze field samples revealed that $100 \%$ (6 of 6

281 batches) of PCR-positive cases had nervous lesions examined by

282 histopathology. Whereas all PCR-negative batches lacked histopathological

283 lesions (Table 2), and no virions were observed by the electron microscopy 
284 using direct negative staining of pooled organs consisting of gonads, the 285 hepatopancreas, intestines, gills, muscles, and mantle. Due to the slow rates 286 of abalone mortality noted in the field, the relationship between these cases 287 and herpesvirus infection needs further study.

\section{Acknowledgements}

290 The authors are grateful to Dr. Mark Crane, Project Leader, and his

291 colleagues at CSIRO Livestock Industries, Australia for providing primer sets

292 and protocols at the beginning of study of this virus in the lab. The authors also

293 thank Dr. Brian Jones, Department of Fisheries of Western Australia, for his

294 valuable comment on histopathology and Dr. Chung Yen Lin and Dr. Sheng

295 Yao Su, Academia Sinica, Taiwan, for their assistance with the PALM analysis.

296 The study was supported by a grant from the Council of Agriculture, Taiwan. 
299 Arzul, I., Renault, T., Thébault, T., Gérard, A., 2002. Detection of oyster

300 herpesvirus DNA and proteins in asymptomatic Crassostrea gigas adults.

$301 \quad$ Virus. Res. 84, 51-160.

302 Arzul, I., Renault, T., Lipart, C., Davison, A.J., 2001a. Evidence for

303 interspecies transmission of oyster herpesvirus in marine bivalves. J. Gen.

$304 \quad$ Virol. 82, 865-870.

305 Arzul. I., Nicolas, J.L., Davison, A.J., Renault, T., 2001b. French Scallops: A

306 New Host for Ostreid Herpesvirus-1. Virol. 290, 342-349.

307 Barbosa-Solomieu, V., Miossec, L., Vázquez-Juárez, R., Ascencio-Valle, F.,

308 Renault, T., 2004. Diagnosis of ostreid herpesvirus 1 in fixed

309 paraffin-embedded archival samples using PCR and in situ hybridisation. J.

$310 \quad$ Virol. Methods. 119, 65-72.

311 Batista, F.M., Arzul, I., Pepin, J.F., Ruano, F., Friedman, C.S., Boudry, P.,

312 Renault, T., 2007. Detection of ostreid herpesvirus 1 DNA by PCR in bivalve molluscs: a critical review, J. Virol. Methods. 139, 1-11.

314 Bozzola, J.J., Russell, L.D., 1992. Electron microscopy: principles and techniques for biologists. Jones and Bartlett, Boston, MA, pp. 108-182. 
316 Braithwaite, D. K., Ito, J., 1993. Compilation, alignment, and phylogenetic relationships of DNA polymerases. Nucleic. Acids. Res. 21, 787-802.

318 Burge, C.A., Strenge, R., Friedman, C.S., 2011. Detection of the oyster herpesvirus in commercial bivalves in northern California, USA: conventional and quantitative PCR. Dis. Aquat. Organ. 94,107-116.

321 Chang, P.H., Kuo, S.T., Lai, S.H., Yang, H.S., Ting, Y.Y., Hsu, C.L., Chen, 322 H.C., 2005. Herpes-like virus infection causing mortality of cultured abalone 323 Haliotis diversicolor supertexta in Taiwan. Dis. Aquat. Organ. 65, 23-27.

324 Chen, S.H., Su, S.Y., Lo, C.Z., Chen, K.H., Huang, T.J., Kuo, B.H., Lin, C.Y., 325 2009. PALM: A Paralleled and integrated framework for phylogenetic 326 inference with automatic likelihood model selectors. PLoS ONE 4. 12: e8116.

328 Corbeil, S., Colling, A., Williams, L.M., Wong, F.Y.K., Savin, K., Warner, S., 329 Murdoch, B., Cogan. N.O.I., Sawbridge, T.I., Fegan, M., Mohammad, I., 330 Sunarto, A., Handlinger, J., Pyecroft, S., Douglas, M., Chang, P.H., Crane, 331 M.StJ., 2010. Development and validation of a TaqMan® PCR assay for 332 the Australian abalone herpes-like virus. Dis. Aquat. Organ. 92, 1-10. 
333 Davison, A.J., Eberle, R., Ehlers, B., Hayard, G.S., McGeoch, D.J., Minson.

334 A.M., Pellett, P.E., Roizman, B., Studdert, M.J.E., Thiry, E., 2009. The

335 order Herpesvirales. Arch. Virol. 154, 171-177.

336 Farley, C.A., Banfield, W.G., Kasnic, G.Jr., Foster, W.S., 1972. Oyster

337 herpes-type virus. Science. 178, 759-760.

338 Hooper, C., Hardy-Smith, P., Handlinger, J., 2007. Ganglioneuritis causing 339 high mortalities in farmed Australian abalone, Haliotis laevigata and Haliotis $340 \quad$ rubra. Aust. Vet. J. 85,188-193.

341 Huang, Y.Y., Wu, W.C., Yan, J.H., Chou, W.B., Chen, S.C., Ni, J.M., Chen,

342 S.T., 1999. Investigation on an exterminate disease of Haliotis diversicolor

343 aquatilis. Fujian. J. Animl. Husband. Vet. 21, 4-5.

344 Le Deuff, R.M., Renault, T., 1999. Purification and partial genome

345 characterization of a herpes-like virus infecting the Japanese oyster,

$346 \quad$ Crassostrea gigas. J. Gen. Virol. 80, 1317-1322.

347 Martenot, C., Oden, E., Travaillé, E., Malas, J.P., Houssin, M., 2010.

348 Comparison of two real-time PCR methods for detection of ostreid

349 herpesvirus 1 in the Pacific oyster Crassostrea gigas. J. Virol. Methods.

$350 \quad 170,86-89$. 
351 Nakatsugawa, T., Nagai, T., Hiya, K., Nishizawa, T., Muroga, K., 1999. A virus 352 isolated from juvenile Japanese black abalone Nordotis discus discus 353 affected with amyotrophia. Dis. Aquat. Organ. 36,159-161.

354 Otsu, R., Sasaki, K., 1997. Virus-like particles detected from juvenile abalones, $355 \quad$ Nordotis discus discus reared with an epizootic fatal wasting disease. J. $356 \quad$ Invertebr. Pathol. 70, 167-168.

357 Renault, T., 2008. Shellfish viruses. Encyclopedia of Virology, Third Edition, $358 \quad$ Elsevier, vol. 4, pp. 560-567.

359 Renault, T., Novoa, B., 2004. Viruses infecting bivalve molluscs. Aquat. Living. $360 \quad$ Resour. 17, 397-409.

361 Renault, T., Arzul, I., 2001. Herpes-like virus infections in hatchery-reared 362 bivalve larvae in Europe: specific viral DNA detection by PCR. J Fish 363 Diseases. 24,161-167.

364 Renault, T., Le Deuff, R.M., Lipart, C., Delsert, C., 2000. Development of a 365 PCR procedure for the detection of a herpes-like virus infecting oysters in 366 France. J. Virol. Methods. 88, 41-50.

367 Savin, K.W., Cocks, B.G., Wong. F., Sawbridge, T., Cogan, N., Savage, D., 368 Warne, S., 2010. A neurotropic herpesvirus infecting the gastropod, 
abalone, shares ancestry with oyster herpesvirus and a herpesvirus associated with the amphioxus genome. Virology. Journal. 7, 308.

371 Segarra, A., Pépin, J.F., Arzul, I., Morga, B., Faury, N., Renault, T., 2010. Detection and description of a particular Ostreid herpesvirus 1 genotype associated with massive mortality outbreaks of Pacific oysters, Crassostrea gigas, in France in 2008. Virus. Res. 153, 92-99.

375 Song, Z.H.R., Ji, R.X., Yan, S.F., Chen, C.S., 2000. A spherovirus resulted in 376 mass mortality of Haliotis diversicolor Aquatilis. J. Fish. China. 24, 463-467.

377 Tan, J., Lancaster, M., Hyatt, A., van Driel, R., Wong, F., Warner, S., 2008.

378 Purification of a herpes-like virus from abalone, Haliotis spp. with 379 ganglioneuritis and detection by transmission electron microscopy. J. Virol. $380 \quad$ Methods. 149, 338-341.

381 Van Nieuwstadt, A.P., Dijkstra, S.G.M., Haenen, O.L., 2001. Persistence of 382 herpesvirus of eel Herpesvirus anguillae in farmed European eel Anguilla 383 anguilla. Dis. Aquat. Organ. 45, 103-107.

384 Wang, B., Li, X., 1997. Infection of spherical viruses from Haliotis discus 385 hannai Ino. Virologica. Sinica. 12, 360-363. 
386 Wang, J.Y., Chen, B.H., Feng, J., Yu. M.Y., 2000. Primary observation of 387 spherical viruses from diversicolor abalone (Haliotis diversicolor Reeve). J. $388 \quad$ Trop. Oceanogr. 12, 63-67.

389 Whitley, R.J., 1996. Herpes simplex viruses. In: Fields BN, Knipe DM, Howley 390 PM (eds) Virology, 3rd ed. Lippincott-Raven Publishers, Philadelphia., pp. $391 \quad 2297-2342$.

392 Zhang, Z.H.X., Wang, J., Su, Y.Q., Yan, Q.P., Chi, X.C., Zhou, H.M., Zhou, 393 Y.C., 2001. Pathogeny and histopathology of the epidemic disease in 394 Haliotis diversicolor supertexta. J. Xiamen. Univ. 40, 949-956. 


\section{Figure captions}

397 Fig. 1. Alignment of the deduced amino acid sequences of Haliotis herpesvirus

398 (AbHV) with the homologous domains of DNA polymerases from different

399 herpesviruses using a PALM analysis. The percentage of replicate trees in the

400 bootstrap test (100 replicates) is shown next to the branches.

401

402 Fig. 2. The PCR detection of AbHV is specific since all irrelevant controls yield

403 negative results. Lane 1, Haliotis herpesvirus (AbHV); lane 2, chicken

404 infectious laryngotracheitis; lane 3, koi herpesvirus; lane 4, eel herpesvirus;

405 lane 5, ostreid herpesvirus (OsHV)-1 DNA; and lane M: 100 bp DNA. The

406 expected fragment size is $606 \mathrm{bp}$ (arrow).

407

408 Fig. 3a. Histology of normal ganglion containing a peripheral layer of glial cells

409 (arrow) of the foot muscle of abalone (M). Scale bar $=25 \mu \mathrm{m}$.

411 Fig. 3b. Haliotis diversicolor supertexta. Histological examination of a ganglion

$412(\mathrm{G})$ associated with the kidney (K). Diffuse necrosis accompanied by infiltration

413 of hemocytes (arrow) and necrotic cells was prominent in the tissue.

414 Haemocytes surrounding neurilemma was evident. Scale bar $=25 \mu \mathrm{m}$. 
416 Fig. 4. TEM examination of a purified Taiwanese abalone herpesvirus

417 presented at the interface of $40 \% \sim 50 \%$ sucrose gradients. Negative staining 418 with PTA. Scale bar $=100 \mathrm{~nm}$. 


\section{Table 1}

421 Comparison of DNA polymerase amino acid sequence between abalone

422 herpesvirus from Taiwan 2004 and herpesviruses of other species.

\begin{tabular}{|c|c|c|}
\hline Accession no.\# & Description & Identity \\
\hline HQ317456 & Abalone herpesvirus Taiwan/2004 & \\
\hline HM631982.2 & Abalone herpesvirus Victoria/AUS & $99 \%(1923 / 1926)$ \\
\hline YP_024639.1 & Ostreid herpesvirus 1 & $30 \%(562 / 1856)$ \\
\hline NP_065512.1 & Alcelaphine herpesvirus 1 & $26 \%(47 / 180)$ \\
\hline NP_076501.1 & Bovine herpesvirus 4 & $26 \%(50 / 193)$ \\
\hline NP_040211.1 & Saimiriine herpesvirus 2 & $46 \%(18 / 39)$ \\
\hline YP_438136.1 & Ovine herpesvirus 2 & $25 \%(45 / 180)$ \\
\hline YP_002321247.1 & Caviid herpesvirus 2 & $34 \%(21 / 62)$ \\
\hline NP_570750.1 & Macacine herpesvirus 5 & $25 \%(47 / 185)$ \\
\hline NP_047983.1 & Ateline herpesvirus 3 & $46 \%(17 / 37)$ \\
\hline |NP_066916.1 & Gallid herpesvirus 3 & $26 \%(19 / 74)$ \\
\hline NP_047983.1 & Ateline herpesvirus 3 & $29 \%(26 / 91)$ \\
\hline YP_004207849.1 & Rodent herpesvirus Peru & $23 \%(39 / 166)$ \\
\hline NP_064160.1 & Murid herpesvirus 2 & $29 \%(25 / 86)$ \\
\hline
\end{tabular}




\begin{tabular}{lll} 
NP_042605.1 & Equid herpesvirus 2 & $24 \%(42 / 174)$ \\
NP_042931.1 & Human herpesvirus 6 & $38 \%(20 / 52)$ \\
NP_612698.1 & Panine herpesvirus 2 & $29 \%(24 / 84)$ \\
YP_068007.1 & Macacine herpesvirus 4 & $23 \%(41 / 181)$ \\
NP_733857.1 & Callitrichine herpesvirus 3 & $36 \%(13 / 36)$ \\
NP_944452.1 & Psittacid herpesvirus 1 & $29 \%(18 / 62)$ \\
NP_116408.1 & Tupaiid herpesvirus 1 & $34 \%(21 / 62)$ \\
NP_044863.1 & Murid herpesvirus 4 & $23 \%(36 / 159)$ \\
NP_077443.1 & Cercopithecine herpesvirus 9 & $33 \%(12 / 36)$ \\
YP_001096184.1 & Cyprinid herpesvirus 3 & $42 \%(27 / 65)$ \\
\hline & Macacine herpesvirus 4 & $23 \%(40 / 177)$
\end{tabular}

424

\#: The accession numbers were taken from the NCBI's GenBank.

425

426

427 


\section{Table 2}

429 Summary of Case histories and results of histopathological and PCR

430 examinations.

431

Case

Date Size History Histopathology $\quad$ PCR

no.

12003 Feb. juvenile mortality

22003 Feb. adult low harvest

32003 Nov. juvenile low harvest

42004 Feb. adult mortality

52004 Feb. adult mortality

62004 Mar. adult low harvest

72004 Mar. adult low harvest

82004 Nov. adult low harvest

92005 Jan. adult mortality

102006 July juvenile low harvest

112006 Dec. adult low harvest

122007 May juvenile low harvest

132008 Jan. adult low harvest 
142008 Jan. adult mortality

152008 Oct. adult mortality

162008 Oct. juvenile low harvest

172008 Oct. juvenile low harvest

182009 Aug. juvenile low harvest

192009 Aug. juvenile low harvest

432 \#: Results revealed that 32 percent (6 batches/19 batches) of PCR positive

433 cases had nervous lesions under histopathology examination. 
Fig. 1.

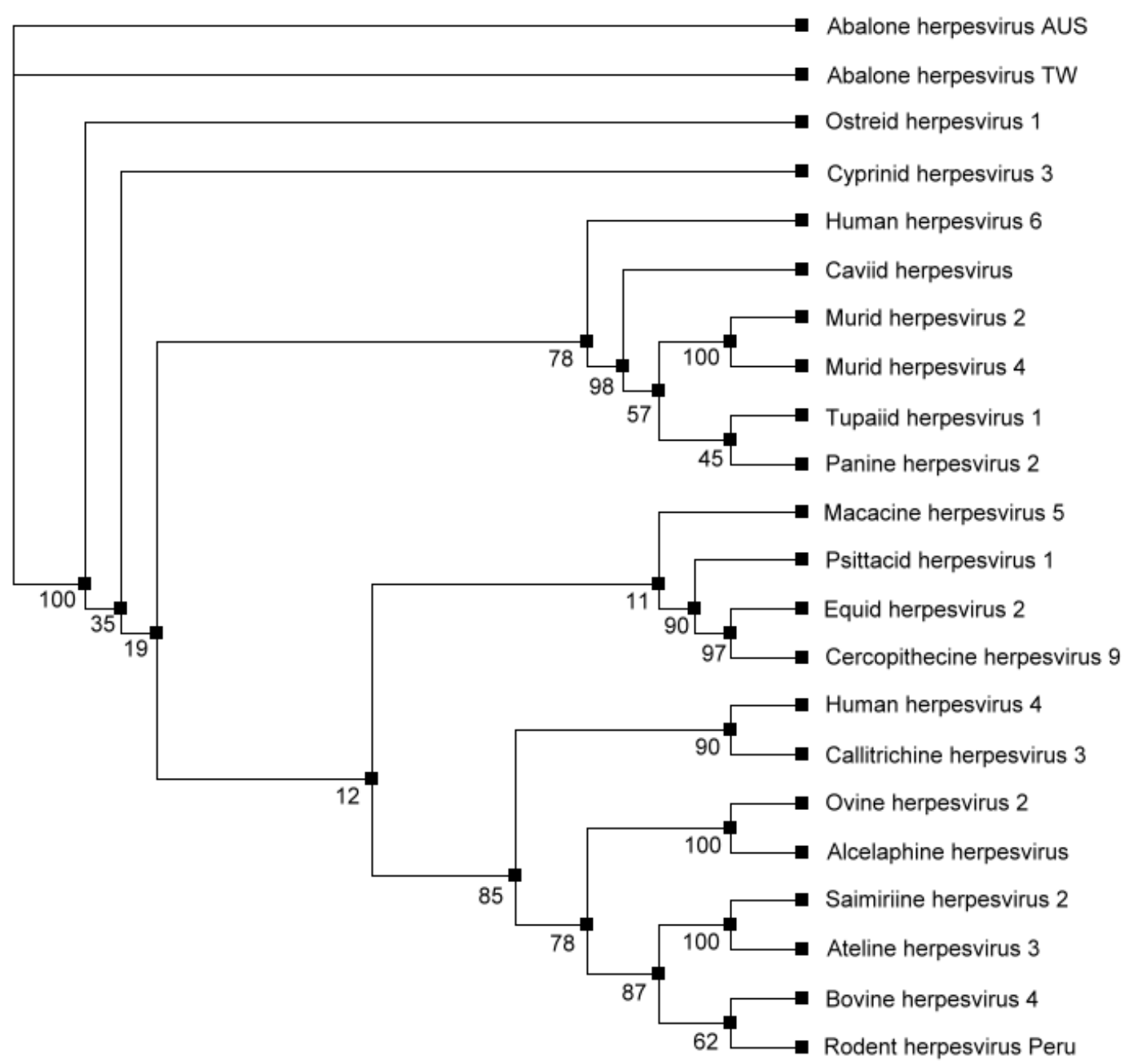


439 Fig. 2.

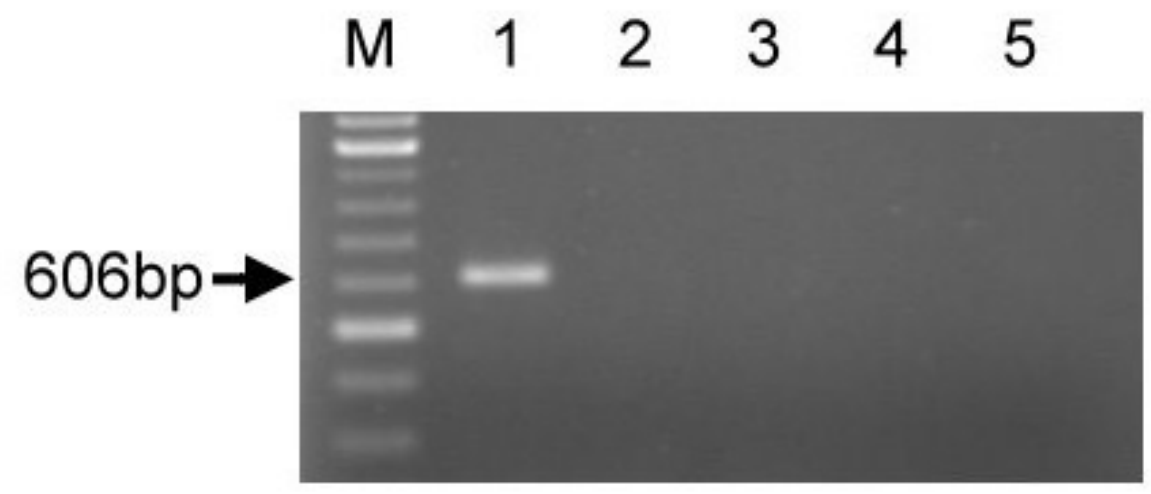

440

441

442

443 
445 Fig. 3a.

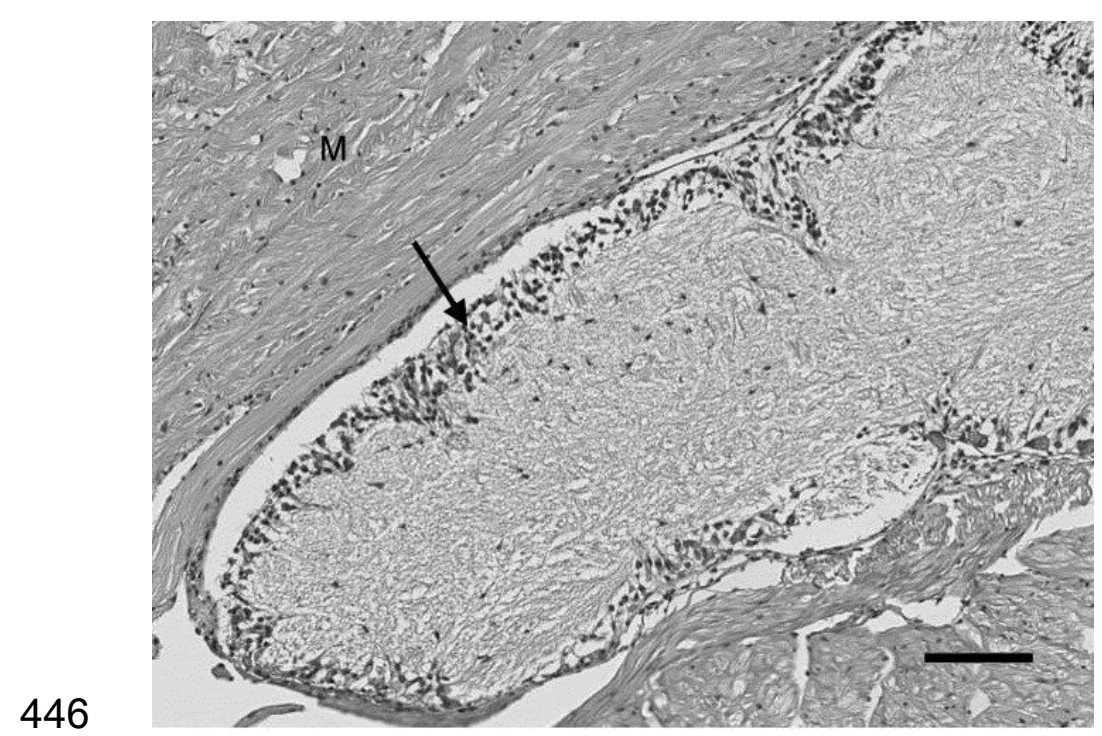


447 Fig. 3b.

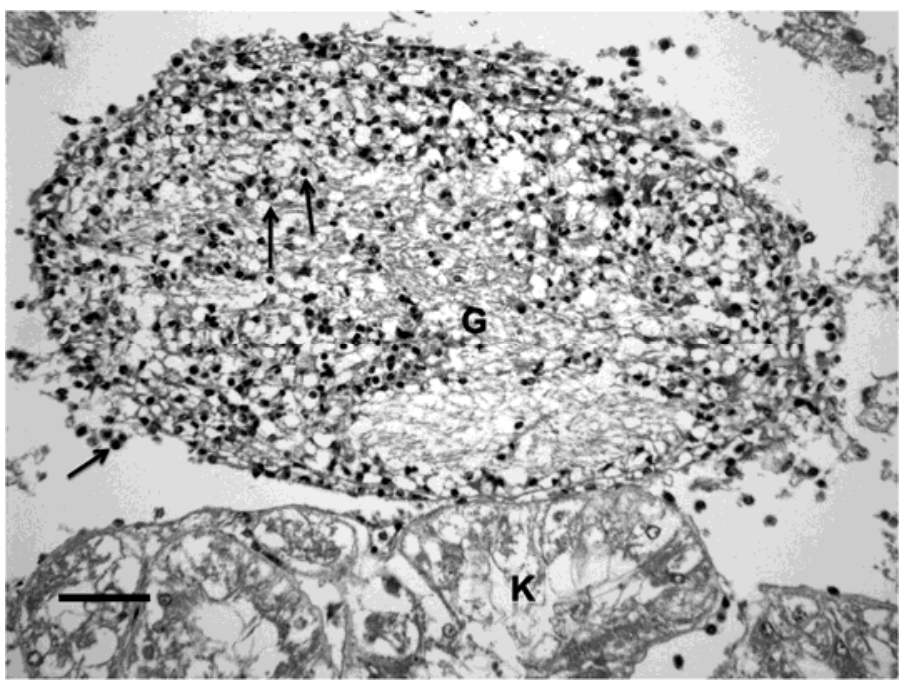

449 
$451 \quad$ Fig. 4.

452

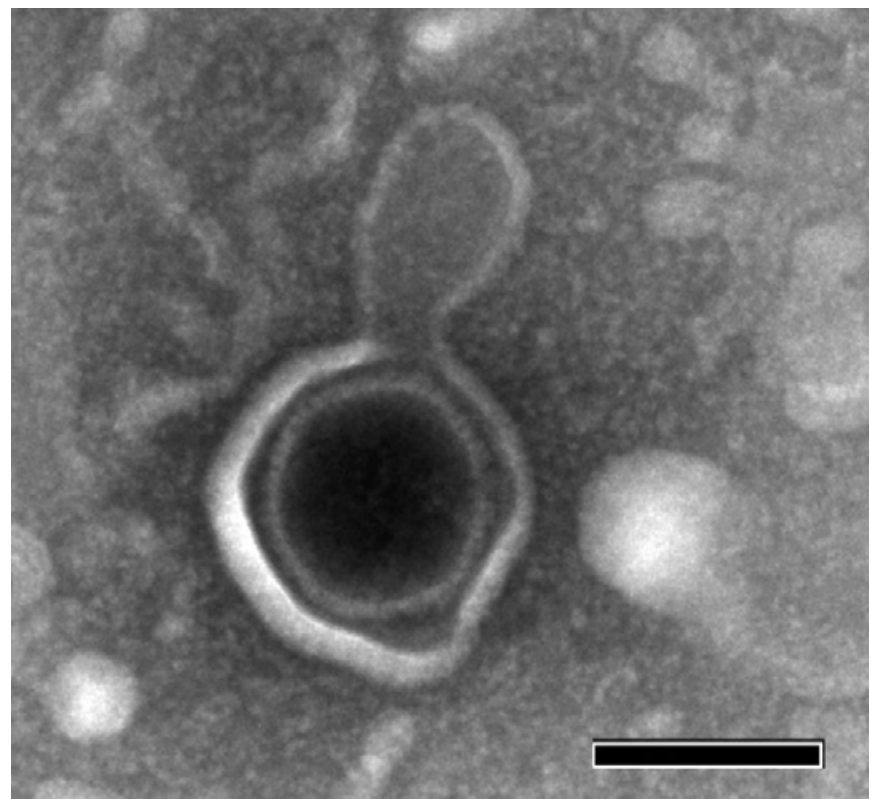

453 